\title{
Hojforræderisigtelsen mod H. P. Hanssen 1895.
}

\section{Af Johannes Andersen.}

Den 3. Februar 1895 afholdt H. P. Hanssen i Mogeltander et politisk Møde, som han - i Overensstemmelse med den dagældende Forenings- og Forsamlingslov - selv havde anmeldt til Myndighederne og indbudt til. Om Mødets Forløb meddelte "Dannevirke" den 5. Februar:

„Møgeltønder, den 4. Februar. Det politiske Møde for Mænd og Kvinder, som Redaktør Hanssen fra A-abenraa afholdt i Gaar Aftes, havde fundet jævnt god Deltagelse. Ved Træk af Verdenshistorien paaviste Foredragsholderen det nationales Betydning for Folkeslagene, og at hvor Nationaliteten er gaaet til Grunde, der er Folket ogsaa gaaet tilbage paa alle Omraader. Han omtalte derefter den nationale Stilling i Sønderjylland og paaviste, hvor godt vi havde holdt den siden 1864, hvorledes Udviklingen af vore Forsvarsmidler altid holder Skridt med Uviklingen af Angrebsmidlerne, og at Gjenforeningen med Danmark var det endelige Maal for vort Forsvar, som vi sikkert ogsaa nok en Gang vilde naa.

Efter Foredraget samledes man ved Bordene, hvor der herskede en munter Stemning, og hvor der veksledes med Taler og Sang. Der blev udtalt Ønsket om, at der rundt om i Sønderjylland maatte blive afholdt politiske Møder for Mænd og Kvinder, for at vi kunne faa Kvinden draget mere med ind $i$ det politiske Røre, saa hun derved bedre end hidtil kom til at tage Del i det politiske Arbejde."

Mødet var altsaa forløbet uden noget som helst Mellemspil, єndogsaa uden et - paa daværende Tidspunkt saare almindeligt - Forsøg fra Myndighedernes Side paa at forstyrre eller opløse det: det havde $-\mathrm{i}$ det mindste tilsyneladende - ikke vakt Opsigt af nogen Art. 
Men den 19. Marts 1895 stævnedes H. P. Hanssen til Afhoring i Amtsretten i Aabenraa. Dette gentog sig den 22. og 26. Marts og endte med, at han den sidstnævnte Dag blev fæengslet som sigtet for Forberedelse af Højforræderi. Efter at have paakæret denne Kendelse til Landsretten i Flensborg, blev han efter 3 Dages Forløb sat paa fri Fod.

Denne Sagens ydre Forløb blev naturligvis omtalt i Dagspressen, men om Sagens Enkeltheder er der mig bekendt hidindtil ikke fremkommet andet end de to Udtalelser fra $H$. $P$. Hanssen selv i hans Blad „Hejmdal“, som findes gengivet i hans ,Et Tilbageblik" II, Side 135 og 136.

Set ud fra det daværende Tidspunkt kan dette næppe overraske. Forklaringen kan dog ikke være den, at Afhøringen var sket i lukkede Retsmøder (efter den daværende tyske Retsplejelov var kun Domsforhandlinger offentlige), thi i Mangel af en udtrykkelig Lovbestemmelse herom antoges det i tysk Fietspraksis ikke for ulovligt, at den sigtede selv gav Oplysninger om sine egne Udtalelser i lukkede Retsmøder. Forklaringen maa vel nok søges $i$ den fuldtud rigtige Slutning, $H$. P. Hanssen selv drog af Sagens Forløb i en af de to nævnte Udtalelser („Det har saaledes vist sig, at H. P. Hanssens hele Virksomhed godt kunde taale en indgaaende Undersøge!se, og at hans Optræden i denne Sag har været korrekt. Domstolene har ikke en Gang faaet Lov til at sysselsætte sig med Sagen, men Overrigsadvokatens af Første Statsadvokat Schwarz attesterede Erklæring er tilstrækkelig til at ophæve al Mistanke og paatrykke H. P. Hanssens politiske Virksomhed Lovlighedens Stempel. Det er alt, hvad der er kommet ud af Højforræderisagen, og dette Resultat er sikkert mere tilfredsstillende for os end for vore politiske Modstandere.")

Den efterfølgende Redegørelse vil vise, hvor rammende denne Bedømmelse af Sagens Forløb var og det endog $i$ endnu højere Grad, end Hanssen - ukendt som han var med Sagens Oprindelse og dens interne Mellemspil — kunde vide. 
Derimod tog han fejl i sin Bedømmelse af Sagens Virkninger paa vore politiske Modstandere.

Den 25. Januar 1899 behandlede den prøjsiske Landdag, af hvilken H. P. Hanssen i Mellemtiden var bleven Medlem, en af den liberale Landdagsmand for Kiel, Dr. Barth $\mathrm{m}$. fl. stillet Forespørgsel til Statsregeringen angaaende Masseudvisningerne af danske Undersaatter fra Nordslesvig med det Formaal at øve et Tryk paa deres dansksindede Arbejdsgivere.

Foresporgslen blev besvaret af Indenrigsminister $v$. d. Recke, der efter nogle indledende Bemærkninger til Forespørgerne rettede et skarpt Angreb imod H. P. Hanssen, idet han - jfr. Franz v. Jessen: Haandbog i det nordslesvigske Spørgsmaals Historie (1901) Side 479 - udtalte:

"Den danske Agitation er vokset i Styrke fra Aar til Aar, og der er navnlig i de senere Aar blevet ført et Sprog, som ligefrem maa betegnes som skandaløst, og som har krænket den tyske Befolkning dybt. Da der imidlertid savnes passende Bestemmelser i Straffeloven, har man ikke til Gavns kunnet modvirke denne Agitation.

Typisk for den danske Agitations Virkemaade og Formaal er en Ytring af Redaktør Hanssen i Aabenraa, Udgiveren af det danske Blad „Hejmdal“. Landdagsmand Hanssen - det er nemlig den sammen Mand - vil ikke kunne nægte, at han er fremkommen med følgende Ytring:

(Her følger saa Oplæsning af den Del af H. P. Hanssens Udtalelser i det afsluttende Forhør den 26. Marts 1895, der nedenfor er gengivet med Kursiv.)

I sit „Et Tilbageblik“ siger H. P. Hanssen selv, at „Oplæsningen af dette Citat vakte uhyre Indignation", - se nærmere herom: Franz v. Jessen: Mit Livs Egne, Hændelser, Mennesker. I. $351 \mathrm{ff}$., navnlig 353 , - og det blev senere Gang efter Gang - som straffefrit Referat af en parlamentarisk Forhandling aftrykt i den nordslesvigske Fortyskningspresse og gik fra denne fra Tid til anden over $\mathrm{i}$ den store tyske Presse. Det blev for- 
synet med Billedet af en højre Haand, paa hvilken de 3 Edsfingre (eller Dele af dem) manglede og - som Tiden gik - udbygget til en Sigtelse for Mened overfor den prøjsiske Forfatning, som H. P. Hanssen som Landdagsmand - før han kunde indtage sit Sæde i Landdagen - havde maattet aflægge Ed paa. Sagsanlæg fra H. P. Hanssen's Side førte kun til ringe Resultater: saaledes fik Redaktør Strackerjan i 1909 en Bøde paa 500,00 Mark for Fornærmelse.

Ved Omstændigheder, der kun har personlig Interesse, blev det mig allerede for mange Aar siden muligt at gennemgaa og tage en udførlig Ekstrakt af Højforræderisagens originale Akter. Da Sagen paa mange Punkter er forløben anderledes, end det hidindtil synes kendt, og alle delagtige Personer nu er døde, nærer jeg ikke mere Betænkeligheder ved at efterkomme et overfor mig fremsat Ønske om offentligt at redegøre for Sagens Gang.

Med Skrivelse af 6. 3. 1895 foresporger den daværende Overpræsident for Provinsen Slesvig-Holsten Zimmermann, der vedlægger en Oversættelse af „Dannevirke"s i Indledningen gengivne Meddelelse om $\mathrm{H}$. P. Hanssens Møde i Møgeltønder den 3. 2. 1895 og en Indberetning af 20. 2. 1895 fra Landraaden, hos Statsadvokaten i Flensborg, om der er indledt Undersøgelse, evt. henstilles en saadan til Overvejelse, "da det - selv om man gaar ud fra, at de paagældende Undersøgelser sandsynligvis vil forløbe uden Resultat - maa synes at være paa sin Plads at tage sig af en dristig Agitation, som faar et saa utilsløret Udtryk, ved at Deltagerne afhørtes under Ansvar og i givet Fald Sagen gaar videre"..)

Af andre indsendte Bilag fremgaar det, at Mødet er blevet

1) sda es selbst bei der Annahme vorraussichtlicher Erfolglosigkeit der entsprechenden Untersuchungshandlungen angezeigt erscheinen muss, dreisten Agitationen, welche einen so unverhüllten Ausdruck annehmen, durch verantwortliche Vernehmung der Beteiligten und geeignetenfalls weitere Erhebung näher zu treten.« 
overværet af Gendarmen i Tønder, da Amtsforstanderen i Bredebro var forhindret, og at Gendarmen har indberettet:

"....... Alt er forlabet roligt"..)

I Amtsforstanderens Indberetning til Landraaden siges, at Gendarmen ikke fuldtud forstaar dansk og hans Indberetning derfor ikke er udtømmende. Men Amtsforstanderen selv har omtrent 4 Uger tidligere hørt Hanssen tale om samme Emne i Døstrup „uden at der er forefaldet noget ulovligt. Det turde da iøvrigt først komme an paa, i hvilken Sammenhæng den Ytring er brugt, som er understreget i Bilaget. I og for sig vilde jeg ikke have oplost Forsamlingen af den Grund, da slige Talemaader kan læses næsten hver Dag i de danske Aviser, uden at Statsadvokaten tager Affære. “s $)$

Som man ser, en meget fornuftig Indstilling, baade i juridisk og praktisk Henseende. Men Landraaden har bedre forstaaet, hvad man venter af ham. Han udtaler som sin Mening, at Forsamlingen burde være oplest, og at der foreligger $\mathbf{H ø j}-$ forræderi. Opløsning af en Forsamling i Henhold til $\S 5$ i Foreningsloven og en Anklage for Overtrædelse af Presseloven er to forskellige Ting, og han tilføjer, at den Omstændighed, at en Statsadvokat virkelig skulde have vist for vidtgaaende Hensyn, ikke kan være bestemmende for Politimyndigheden.

Paa den her skildrede Baggrund anmoder Statsadvokaten i Flensborg Amtsretten i Aabenraa om at stæ.vne H. P. Hanssen til Forhør og udstede Arrestordre.

Det fremgaar ikke af Sagen, hvem der har foranlediget Overpræsidentens Forespørgsel og Henstilling til Statsadvokaten, eller hvem der har forsynet ham med de første Oplysninger. Man kan kun formode, at det er den Angiverkommission,

2) $\gg \ldots \ldots \ldots \ldots$ Es ist alles ruhig verlaufen..

3) 》ohne dass etwas Ungesetzliches vorgefallen ist. Es dürfie doch übrigens zunächst darauf ankommen, in welchem Zusammenhang die in der Anlage unterstrichene Ausserung gebraucht ist. An und für sich würde ich die Versammlung daraufhin nicht aufgelöst haben, da derartige Redewendungen fast täglich in den dänischen Zeitungen zu lesen sind, ohne dass die Staatsanwaltschaft dagegen einschreitet*. 
som $\mathrm{H}$. P. Hanssen omtaler i sit Svar til Indenrigsminister $v$. d. Recke i den prøjsiske Landdags i Indledningen omtalte Møde den 25. 1. 1899 (,saa meget mere som den tyske Forening i Nordslesvig har dannet en Angiverkommission, der læser de politiske Artikler i vore Aviser og sørger for, at de paagældende Redaktører og Journalister drages til Ansvar" - jfr. Franz v. Jessen: Haandbog Side 485).

Den 19. Marts 1895 begynder saa Forhøret over H. P. Hanssen. Det foretages af den som ivrig Tvangsfortyskningsmand og senere navnlig gennem sin Deltagelse i Forsøgene paa at fratage dansksindede Forældre Forældremyndigheden kendte Amtsdommer Lindemann. Det fylder over 11 Sider. Efter at der er optaget, hvad vi nu bedst kender under Betegnelsen „Generaliarapport“, udtaler H. P. Hanssen:4)

4) „Ich habe am 3. II. ds. J. in Mögeltondern eine öffentliche politische Versammlung einberufen und in meinem Vortrag mich über die nationale und politische Stellung unserer dänischen Partei in Nordschleswig weiter ausgelassen.

Ich habe inhaltlich gesagt, ein Volk, welches seine Nationalität verliere, gehe sittlich und wirtschaftlich zurück. Unsere nationale Stellung seit 1864 in Südjütland sei in Bezug auf die dänische Volkssprache, auf die dänische politische Gesinnung der Grundbesitzer, auf Wahlen, abgesehen von Flensburg, im ganzen die gleiche geblieben. Ich habe weiter angeführt, wie würde es in Zukunft werden, die Angriffsmittel der deutschen Regierung in Bezug auf den deutschen Unterricht, die allgemeine Schulpflicht, Vereins- und Versammlungsrecht, Polizeirecht sind schärfer geworden und hemmen die Ausbreitung unserer Partei, aber unsere Verteidigungsmittel zur Ausbreitung unserer Muttersprache und unserer dänischen Gesinnung sind stärker geworcen, namentlich durch Ausnützung der Presse, des Vereins- und Versámmlungsgesetzes, insbesondere durch die dänischen Sprachvereine, aie Vortragsvereine, den Schulverein für Nordschleswig und die politischen Versammlungen. Unsere Verteidigungsmittel sind auch für die Zukunft den Angriffsmitteln der deutschen Regierung gewachsen. Wenn wir unsere Nationalität verteidigen, so hat es einen Wert in sich, so geschieht es aber auch in der Hoffnung, eine politische Wiedervereinigung mit Dänemark in der Zukunft $\mathrm{zu}$ erreichen, denn nur in der Vereinigung mit Dänemark sichern wir unsere Nationalität.

Ich bin der Auffassung, dass später einmal Veränderungen in der politischen Lage eintreten können, sodass Deutschland auf friedlichem Wege Nordschleswig an Dänemark abgeben könne, wie, vermag ich nicht zu sagen. Die Hoffnung auf einen Krieg und mögliche Niederlage Deutschlands habe ich nicht. Diese Auffassung einer Vereinigung 
Jeg har den 3. 2. d. Aar indkaldt til et offentligt politisk Møde i Møgeltønder og i mit Foredrag udtalt mig udførligere om vort danske Parti i Nordslesvigs nationale og politiske Stilling.

Hvad Indholdet af min Tale angaar, har jeg sagt, at et Folk, som mister sin Nationalitet, gaar det tilbage for moralsk og økonomisk. Vor nationale Stilling i Sønderjylland er, sagde jeg, siden 1864 i det store og hele forblevet den samme saavel hvad angaar det danske Folkemaal som Grundejernes danske politiske Sindelag og Valgene, naar undtages Flensborg. Jeg har videre udtalt, hvorledes det vel vilde blive i Fremtiden: Den tyske Regerings Angrebsmidler med Hensyn til den tyske Undervisning, den almindelige Skolepligt, Forenings- og Forsamlingsretten, Politiforordningerne er blevet skærpede og vanskeliggør Udbredelsen af vort Parti, men vore Forsvarsmidler til Udbredelse af vort Modersmaal og vort danske Sindelag er bleven stærkere, navnlig ved Udnyttelse af Pressen og af Forenings- og Forsamlingsloven, i Særdeleshed gennem den danske Sprogforening, Foredragsforeninger, Skoleforeningen for Nordslesvig og de politiske Forsamlinger. Vore Forsvarsmidler kan ogsaa i Fremtiden tage det op med den tyske Regerings Angrebsmidler. Naar vi forsvarer vor Nationalitet, saa har det sit Værd i sig selv, det sker imidlertid ogsaa i Haabet om i Fremtiden at opnaa en politisk Genforening med Danmark, thi kun i Foreningen med Danmark sikrer vi vor Nationalitet.

Jeg er af den Opfattelse, at der senere engang kan indtræde Forandringer i den politiske Situation, saa Tyskland kunde af-

mit Dänemark habe ich in der Versammlung nur dadurch zum Ausdruck gebracht, dass ich hingewiesen habe auf die t'bergabe der Jonischen Inseln seitens Englands an Griechenland und auf die ṫbergabe Helgolands seitens Englands an das Deutsche Reich.

Ich habe ferner angeführt, dass zur Stärkung der dänischen $\mathrm{Na}-$ tionalität politische Versammlungen unter Hinzuziehung der Frauen abgehalten werden müssten, um die Frauen für die Pflege der dänischen Sprache ihrer Kinder zu gewinnen.» 
staa Nordslesvig til Danmark ad fredelig Vej, hvorledes formaar jeg ikke at sige. Jeg haaber ikke paa en Krig og Tysklands mulige Nederlag. Denne Opfattelse af en Forening med Danmark har jeg paa Mødet kun givet Udtryk for paa den Maade, at jeg har henvist til, at England har overladt de ioniske Øer til Grækenland, og at England har overgivet Helgoland til Det tyske Rige. Jeg har endvidere anført, at den danske Nationalitet maa styrkes ved politiske Forsamlinger, som ogsaa Kvinder skal deltage i, for at Kvinderne kan gøres interesserede $i$ at holde det danske Sprog vedlige hos deres Børn.

Forhøret fortscettes den 22. Marts 1895 med følgende Udtalelse af H. P. Hanssen: ${ }^{5}$ )

At Nordslesvigs Løsrivelse fra Tyskland er et højforræderisk Foretagende, indrømmer jeg. Det danske Parti tilsigter ikke og min Virksomhed gaar ikke ud paa en voldelig Adskillelse af Nordslesvig.

En nær forestaaende Forening af Nordslesvig med Danmark er ligesaa lidt Arbejdsmaal for mig som for mine nærmeste Meningsfæller, fordi jeg holder den for umulig, og en For-

5) „Dass die Losreissung Nordschleswig's von Deutschland ein hochverräterisches Unternehmen ist, gebe ich zu. Auf eine gewaltsame Trennung Nordschleswigs geht das Bestreben der dänischen Partei und mein Wirken nicht.

Mit meinen nächsten Gesinnungsgenossen gehe ich nicht auf eine nahe Herbeiführung der Vereinigung Nordschleswigs mit Dänemark, weil ich sie für unmöglich halte und bei einer Niederlage Deutschlands die herbeigeführte Vereinigung nur für vorrübergehend halte, sondern wir suchen die Vereinigung Nordschleswigs mit Dänemark auf friedlichem Wege für die Zukunft vorzubereiten. Das uns gesteckte $\mathrm{Ziel}$ ist meiner Ansicht nach erst in weiter Ferne zu erreichen. $\mathrm{Zu}-$ nächst gehen wir darauf los, durch die oben genannten Verteidigungsmittel, Presse, straffe Organisation, unsere dänische Gesinnung, Nationalität und Sprache in Nordschleswig uns zu erhalten und auszubreiten.

Von der jetzigen Regierung erhoffe ich nichts, wohl aber von einer freisinnigen demokratischen Regierung; unter derselben würde ich, wenn wir unsere Nationalität uns bis dahin gewahrt haben, für möglich halten, dass das im Prager Frieden durch Napoleon zum Ausdruck gebrachte Nationalitätsprinzip anerkannt und durchgeführt werden wird.

Dann kann bei einer gleichzeitigen freundlichen Stellung Deutschlands und Dänemarks eine Abtretung eines national dänischen Nordschleswigs an Dänemark möglich sein. 
ening som Følge af et Nederlag for Tyskland efter min Mening kun vilde være forbigaaende, nej, vi søger ad fredelig Vej at forberede Nordslesvigs Forening med Danmark i Fremtiden. Vort Maal kan efter min Opfattelse først naas i en fjern Fremtid. Vort Arbejde gaar ud paa gennem de oven nævnte Forsvarsmidler, Presse, stram Organisation, at opretholde og udbrede vort danske Sindelag, vor Nationalitet og vort Sprog i Nordslesvig.

Den nuværende Regering kan jeg ikke vente noget af, derimod nok af en frisindet demokratisk Regering; under en saadan vilde jeg holde det for muligt, at, hvis vi indtil da havde bevaret vor Nationalitet, Nationalitetsprincippet, som det ved Napoleons Medvirkning er kommet til Udtryk i Pragfreden, vil blive anerkendt og gennemført. Da kan - en til den Tid venlig Holdning mellem Tyskland og Danmark forudsat - en Afstaaelse af et nationalt dansk Nordslesvig til Danmark være mulig.

Aber nur dann und soweit Nordschleswig noch dänische Gesinnung, dänisches Nationalgefühl und dänische Sprache hat.

Würde im Laufe der Jahre dänisches Nationalgefühl, Gesinnung und Sprache verloren gehen, so würde diese Vereinigung Nordschleswigs mit Dänemark, welche unser Ziel ist, unmöglich sein, und deshalb eben treten wir für die Erhaltung unserer Sprache, Gesinnung und Nationalität ein

Würden wir ruhig sein, nicht agitieren, so würde eben das Deutschtum unsere Nationalität, welçhe wir auch aus etischen Gründen zu erhalten wünschen, verdrängen.

Und deshalb suchen wir das Gefühl der nationalen Zusammengehörigkeit mit Dänemark wach zu erhalten.

Ich suche für dieses durch die Presse, durch Abhaltung von Versammlungen und Vorträge, durch Betätigung in Vereinen zu wirken.

Ich ergreife nur gesetzlich zulässige Mittel.

Durch unsere Tätigkeit wird die hiesige Bevölkerung beunruhigt, wie durch die Agitation einer jeder anderen Oppositionspartei. Dass das Volk aufgereizt wird gegen die deutsche Regierung, bestreite ich; wohl gebe ich zu, dass ich Unzufriedenheit im Volke zu erregen suche gegen die Anweisung der kgl. Regierung in Schleswig betreffs den Unterricht in den Schulen vom 18. XII. 1888, weil ich diese Massregel für die Frhaltung unserer dänischen Sprache gefährlich finde und schädlich für die Ausbildung der Jugend.

Aber dieselbe Unzufriedenheit wird ia von Predigern in Nordschleswig gleichfalls geteilt und erregt $\ll$. 
Men kun da og kun forsaavidt Nordslesvig endnu har dansk Sindelag, dansk Nationalfølelse og dansk Sprog.

Dersom i Aarenes Løb dansk Nationalfølelse, dansk Sindelag og dansk Sprog gik tabt, vilde denne Nordslesvigs Forening med Danmark, som er vort Maal, være umulig, og netop derfor lægger vi os i Selen for at opretholde vort Sprog, vort Sindelag og vor Nationalitet.

Hvis vi forholdt os rolige, ikke agiterede, saa vilde Tyskheden jo fortrænge vor Nationalitet, som vi onsker at opretholde cgsaa af etiske Grunde.

Og derfor søger vi at holde Følelsen af national Samhørighed med Danmark i Live.

Jeg søger at virke herfor gennem Pressen, ved Afholdelse af Møder, ved Foredrag, ved Virksomheden i Foreninger.

Jeg anvender kun lovhjemlede Midler.

Naar det maaske kan siges, at den herværende Befolkning foruroliges ved vor Virksomhed, saa kan det paa samme Maade hævdes om Agitationen af ethvert andet Oppositionsparti. At Befolkningen ophidses mod den tyske Regering, bestrider jeg. Derimod indrømmer jeg, at jeg søger at fremkalde Utilfredshed i Befolkningen mod den kgl. Regering i Slesvigs Skoleforordning af 18. 12. 1888, fordi jeg anser denne Forholdsregel som farlig for Opretholdelsen af vort danske Sprog og for skadelig for Ungdommen under dens Uddannelse.

Men denne Utilfredshed deles og fremkaldes jo paa samme Maade af Præster i Nordslesvig.

Det tredie og sidste Forhør afholdtes Ugedagen efter det forste: den 26. Marts 1895, og H. P. Hanssen udtaler:")

Fra Juli 1888 har jeg virket som Sekretær for Nordslesvigs Vælgerforening; samme har jeg organiseret, og siden da

i) Seit Juli 1888 bin ich als Sekretär des Wählervereins für Nordschleswig tätig; denselben habe ich organisiert und habe seitdem Vorträge gehalten, etwa 50 im Jahre, wovon etwa $10-15$ politische. Seit 1889 habe ich die süderjütischen Jahrbücher (Sønderjydske Aarb $\phi g e r)$ redigiert und in Verbindung mit dem Abgeordneten Johannsen und 
har jeg holdt Foredrag, omtrent 50 om Aaret, hvoraf 10-15 politiske. Siden 1889 har jeg redigeret og sammen med Rigsdagsmand Johannsen og Gaardejer Skau udgivet Sønderjydske Aarbøger. I Oktober 1893 har jeg overtaget Forlag og Redaktion af Dagbladet Hejmdal, som endnu ledes af mig. Jeg er Medstifter og Bestyrelsesmedlem af Skoleforeningen for Nordslesvig siden 1893; fra 1892 Bestyrelsesmedlem i Sprogforeningen for Nordslesvig.

I disse Stillinger og gennem dem har jeg ogsaa virket for Opretholdelse og Udbredelse af dansk Sprog, dansk Sindelag og dansk Nationalitet blandt Nordslesvigs Befolkning, i første Omgang for at opretholde vor danske Nationalitet i Nordslesvig og at holde Følelsen af Samhørighed med det danske Folk vaagen for paa denne Maade at muliggøre en senere Forening af det dansksindede Nordslesvig med Danmark; Maaden, det maatte ske paa, overlader jeg til Fremtiden og til senere Slægtled.

Hofbesitzer Skau herausgegeben. Im Oktober 1893 habe ich den Verlag und die Redaktion der von mir noch jetzt geleiteten Zeitung Hejmdal übernommen. Ich bin Mitstifter und Vorstandsmitglied des Schulvereins für Nordschleswig seit 1893; seit 1892 Vorstandsmitglied des Sprachvereins für Nordschleswig.

In diesen Stellungen und durch dieselben habe ich auch für Erhaltung und Ausbreitung der dänischen Sprache, dänischen Gesinnung und dänischen Nationalität unter der Bevölkerung Nordschleswigs gewirkt, zunächst um unsere dänische Nationalität in Nordschleswig aufrecht zu erhalten und das Gefühl der Zusammengehörigkeit mit dem dänischen Volke rege zu erhalten, um so eine spätere Vereinigung des dänisch gesonnenen Nordschleswigs mit Dänemark möglich zu machen; das $\gg$ wie überlasse ich der Zukunft und späteren Generationen.

Ich werde die gewünschte und geplante Vereinigung mit Dänemark wohl nicht erleben, weil ich unsere jetzige Ohnmacht einsehe; ich gebe mich nur mit dem erreichbaren Ziele der Ausbreitung der dänischen Nationalität in Nordschleswig von der Königsau bis Flensburger Föhrde bis Tondern ab. Dieses ist die Grundbedingung für eine Vereinigurıg Nordschleswigs mit Dänemark.

Wie die Vereinigung dermaleinst vor sich gehen wird, das vermag ich jetzt nicht anzugeben, das hängt von den jeweiligen Umständen ab.

Ich habe oben einige Beispiele angegeben; dieselben sind aber keineswegs erschöpfend.

Ein Krieg Deutschland's mit Dänemark würde für die Söhne unseres Landes, welche in der deutschen Armee dienen, ein Unglück sein; aber wenn durch einen Krieg mit Deutschland eine dauernde Ver- 
Jeg vil vel ikke opleve den ønskede og planlagte Forening med Danmark, al den Stund jeg indser vor nuværende Afmærst; jeg befatter mig kun med det Maal, som kan naas, nemlig, at udbrede den danske Nationalitet i Nordslesvig fra Kongeaaen til Flensborg Fjord og til Tønder. Dette er Grundbetingelsen for Nordslesvigs Forening med Danmark.

Hvorledes Foreningen engang i Fremtiden vil kunne gaa for sig, ser jeg mig nu ikke i Stand til at sige noget om, det afhænger af Omstændighederne til den Tid.

Jeg har ovenfor anført nogle Eksempler; de er imidlertid paa ingen Maade udtømmende.

En Krig mellem Tyskland og Danmark vilde vare en Ulyk$k e$ for vort Lands Sønner, som aftjener deres Varnepligt $i$ den tyske Hor, men dersom en varig Forening af Nordslesvig med Danmark kunde opnaasved en Krig med Tyskland, hvad jegforeløbig holder for umuligt, saa vilde jeg ikke modsctte mig denne

einigung Nordschleswigs mit Dänemark herbeigeführt würde, was ich zunächst für unmöglich halte, so würde ich dieser Lösung der nordschleswigschen Frage nicht entgegentreten.

Ich würde jede Vereinigung Nordschleswigs mit Dänemark, welche ich als dauern ansehe, wünschenswert halten und zustimmen; denn ich wünsche nicht, dass Nordschleswig deutsche Sprache, deutsche Gesinnung, deutsche Nationalität erhält, deutsch wird und deutsch bleibt.

Keine Massregel der deutschen Regierung auf Einführung der däuischen Sprache in Kirche, Schulen und vor Behörden würde mir Genüge sein und mich von der Agitation abhalten.

Die dauernde Trennung Nordschleswigs von Deutschland ist das Ziel meiner Wünsche.

Ich habe in politischen Vorträgen gesagt bezüglich der Vereinigung Nordschleswigs mit Dänemark, wir können das Beste hoffen, nämlich die baldige dauernde Vereinigung, wir müssen uns auf das Schlimmste gefasst machen, nämlich eine langjährige Verbindung mit Deutschland, wodurch unsere Nationalität sehr gefährdet wird. Denn würden wir einige hundert Jahre bei Deutschland bleiben, würden wir voraussichtlich nie davon kommen; eine dänische Frage in Nordschleswig dann wahrscheinlich nicht mehr vorhanden sein.

Diesen Zusatz habe ich natürlich nicht ausgesprochen, um die Hörer nicht zaghaft zu machen. um nicht meine Agitation abzuschwächen. Ich habe aber in den Versammlungen von den möglich schlimmen Folgen gesprochen, um auf die Hörer einen Druck auszuüben und sie zu bewegen, sich straff zu organisieren, sich in Vereinen zusammen zu tun und selber für Ausbreitung und Aufrechterhaltung der dänischen Sprache, dänischen Gesinnung und dänischen Nationalität in ihren Kreisen mitzuwirken.\& 
Løsning af det nordslesvigske Spørgsmaal. Jeg vilde holde enhver Forening af Nordslesvig med Danmark, som jeg kunde antage som varig, for ønskelig og give den min Tilslutning; thi jeg onsker ikke, at Nordslesvig faar tysk Sprog, tysk. Sindelag og tysk Nationalitet, bliver tysk og forbliver tysk.

Ingen Forholdsregel fra den tyske Regerings Side ved Indførelse af dansk Sprog i Kirke, Skole og Administration vilde vcere mig nok og afholde mig fra Agitation.

Nordslesvigs varige Adskillelse fra Tyskland er mine Ønskers Maal.

Jeg har i politiske Foredrag sagt om Nordslesvigs Forening med Danmark, at vi kan haabe paa det bedste, nemlig en snarlig varig Forening, men maa belave os paa det værste, nemlig en Forbindelse med Tyskland i mange Aar, som kan være en Fare for vor Nationalitet. Thi skulde vi forblive ved Tyskland i nogle Hundrede Aar, vilde vi formentlig aldrig komme derfra; et dansk Spørgsmaal i Nordslesvig vilde da sandsynligvis ikke mere være tilstede.

Dette sidste har jeg naturligvis ikke udtalt for ikke at berøve Tilhørerne Modet og for ikke at afsvække min Agitation. Men jeg har ved Møderne talt om de muligvis slemme Følger for at øve et Pres paa Tilhørerne og faa dem til at organisere sig forsvarligt, at slutte sig sammen i Foreninger og i deres Kredse selv at medvirke til Udbredelse og Opretholdelse af dansk Sprog, dansk Sindelag og dansk Nationalitet.

Forhøret slutter med, at der afsiges Fængslingskendelse, der paakæres af H. P. Hanssen til Landsretten i Flensborg, medens Statsadvokaten paastaar Kæren afvist. Men Landsretten ophæver Fængslingskendelsen, „fordi et bestemt, paa Nordslesvigs Løsrivelse fra det prøjsiske Statsomraade sigtende højforræderisk Forehavende, til hvilket den d. 3. Februar d. Aar i Møgeltønder af Tiltalte for en offentlig Forsamling holdte Tale og sammes øvrige agitatoriske Virksomhed skulde danne forberedende Handlinger, ikke kan fastslaas som af ham maalsat og 
planlagt med en Tydelighed, saa Kravet om tilstrækkelig stærk Mistanke kan siges at være opfyldt. " $)$

Kendelsen er afsagt af Landsdommerne Mannhardt, Mohr og v. Hartwig. Men H. P. Hanssen blev ikke løsladt, og der følger nu et Efterspil, der - som saa ofte - er det artigste. Men for fuldtud at forstaa dette, vil det være nødvendigt her at indflette en kort Fremstilling af den i Aaret 1895 gældende tyske Stats- og Strafferet.

Tyskland eller som det officielt hed: det tyske Rige var en Forbundsstat, og der kunde altsaa begaas Højforræderi saavel imod Riget som saadant som imod hver enkelt Forbundsstat. Det sidste vilde for Eksempel foreligge klart ved et Forsøg paa at indlemme en Del af Prøjsen i Hamborg,*) der som fri Hansaby var en selvstændig Forbundsstat. H. P. Hanssen sigtedes imidlertid for at forberede Løsrivelsen af Nordslesvig (en Del af Riget) for at indlemme (genforene) det med Danmark.**) Det var altsaa en klar Sigtelse for Højforræderi imod Riget. Og Sondringen imelem Højforræderi imod Riget og den enkelte Forbundsstat, her altsaa Prøjsen, var ogsaa i anden Henseende af Betydning.

Efter "Gerichtsverfassungsesetz“ $\S 136$ 1. Stk. Nr. 1 var Rigsretten i Leipzig første og sidste Instans „für die Untersuchung und Entscheidung" i Højforræderisager imod Riget, og Statsadvokatens Forretninger ved Rigsretten var efter $\S 143$ Stkr. $1 \mathrm{Nr} .1$ i samme Lov henlagt til Overrigsadvokaten.

Derimod var Højforræderi imod den enkelte Forbundsstat undergivet de almindelige Rettergangsbestemmelser: Stats-

7) Weil ein bestimmtes, auf die Losreissung Nordschleswigs vom preussischen Staatsgebiet gerichtetes hochverrätisches Unternehmen, zu welchem die am 3. Februar ds. J. in Mögeltondern vom Angeschuldigten vor einer öffentlichen Versammlung gehaltenen Rede und die sonstige agitatorische Tätigkeit desselben vorbereitende Handlungen bilden sollen, als von ihm ins Auge gefasst und geplant nicht bis zur Erfüllung eines hinreichend dringenden Verdachts erkennbar ist \&.

*) Tysk Straffelovs § 81 1. Stk. Nr. 4.

**) s. Sted Nr. 3. 
advokatens Forretninger altsaa henlagt til Statsadvokaten og Paadømmelsen - af Hensyn til Straffens Art og Størrelse til Edsvorneretterne (Nævningeting).

Nævnes bør maaske endnu, at der i tysk Retsvidenskab var Strid om, hvorvidt Højforræderi imod Riget ikke ogsaa altid var Højforræderi imod den enkelte Forbundsstat. Men nogen praktisk Betydning havde denne Kathederstrid ikke, da der selvfølgelig kun kunde ske Domfældelse een Gang for den samme Handling.

Da nu Amtsdommer Lindemann modtager Meddelelse om Landsrettens Kendelse, ncegter han at løslade H. P. Hanssen, da hans Arrestordre er begrundet med Sigtelsen for Højforræderi imod Tyskland (altsaa Riget), medens Landsretten har ophævet en Arrestordre for Højforræderi imod Prøjsen. Han hævder derfor, atLandsretten har været ukompetent, og at hans Fængslingskendelse ikke kan ophæves af Landsretten, men kun af Rigsretten, Lindemann anmoder derfor om Henvisning af Sagen til Overrigsadvokaten.

Statsadvokaten giver derfor paany Anvisning om at løslade H. P. Hanssen: han agter kun at rejse Sag for Højforræderi imod Prøjsen, men har dog paakæret Landsrettens Kendelse med den Begrundelse, at „den bestemte Udformning af Forehavendet, som den lavere Instans [Landsretten] savner, er givet, naar Maalet for Forehavendet staar fast" ${ }^{8}$ )

Ved Oversendelsen af Akterne bemærker Landsretten, at den ikke anser det nye yderligere Kæremaal for begrundet, og Overstatsadvokaten i Kiel, gennem hvem Statsadvokaten i Flensborg indsender Akterne, henviser til, at Sagen maa sendes til Overrigsadvokaten, da Højforræderiet er rettet imod Tyskland, og Statsadvokaten sender nu Indberetning til Overrigsadvokaten (og Justitsministeren), og telegraferer til Amts-

8) „die Bestimmtheit des Unternehmens, die der Vorderrichter vermisst, ist gegeben, wenn des Unternehmens Ziel feststeht«. 
retten i Aabenraa om at sætte Hanssen paa fri Fod. Og først nu sker Løsladelsen.*)

I sit Svar udtaler Overrigsadvokaten, at der foreligger Højforræderi imod Tyskland, men han agter ikke at fremme Statsadvokatens yderligere Kæremaal, skønt Landsretten ikke var kompetent, da Fængslingskendelsens Ophævelse er sagligt rigtig.

Straffelovens $\S 85$ (offentlig Opfordring til en Handling, der umiddelbart skal føre til Højforræderiets Udførelse) kan ikke anvendes, da „der ikke foreligger tilstrækkelige Holdepunkter for, at Sigtede har fremsat en Opfordring til umiddelbar Gennemførelse af en højforræderisk Handling“.

Derimod vilde Straffelovens $\S 86$ (forberedende Handling til Højforræderi) nok kunne anvendes, da der hertil ikke udkræves, at Tidspunktet for Handlingens Gennemførelse allerede er bestemt, og Overrigsadvokaten fortsætter:

$\S 85 \mathrm{kan}$ ikke anvendes, „fordi der ikke er tilstrækkelig Grundlag til at antage, at Tiltalte har opfordret til en højforræderisk Handling, som umiddelbart skulde bringes til Udførelse“ $\left.\left(\S 82,81^{3}\right) .{ }^{9}\right)$

$\S 86$ er tilstrækkelig individualiseret; derimod er der ikke fremkommet tilstrækkelige Beviser for derudover - hvad der er nødvendigt - at kunne fastslaa, at Indlemmelsen skal ske ved Magt ( $\$ 81$, Nr. 3), og af hvilken Art dette Magtmiddel vilde være. Ligesaa savnes tilstrækkelige Holdepunkter for hvad der endvidere maa kræves - at kunne paavise de konkrete Midler, ved hvilke det konkrete endelige Maal skal opnaas, Henvisningen til det af Tiltalte angivne Middel, at ud-

") "weil für die Annahme, dass der Beschuldigte eine Aufforderung zu einer unmittelbar zur Ausführung zu bringenden hochverräterischen Handlung $\left(\S 82,81^{3}\right)$ erlassen habe, kein genügender Anhalt gegeben ist «.

*) Redaktør Bjørn Hanssen, Aabenraa, har velvilligst oplyst, at hans Fader blev løsladt den 29. Marts $1895 \mathrm{Kl}$. 20 "efter at Lindemann Kl. 19 havde faaet Telegram fra Statsadvokaten.. 
nytte Presse-, Forenings- og Forsamlingsretten til at fremme og vedligeholdę dansk Nationalbevidsthed og at vinde og opretholde en Indflydelse paa Ungdommens Opdragelse i denne Aand, vilde ikke være tilstrækkelig, saa længe det ikke kan ses, at denne Udnyttelse og hin Indflydelse har faaet en bestemt afgrænset Form, f. Eks. i konkrete Organisationer med obligatoriske Vedtægter. Som Sagen nu staar, er det efter Rigsrettens hidtidige Praksis haabløst at ville opnaa en Domfældelse“. ${ }^{10}$ )

Mon det nu ikke er et mildt Udtryk at sige, at man forbavses over Amtsdommer Lindemanns Embedsførelse? Da hans Fængslingskendelse ophæves af Landsretten, erklærer han denne for inkompetent, uden selv at opdage, at saa ogsaa han selv allerførst har været det. Foreligger der Højforræderi imod Riget - og det hævder Amtsdommer Lindemann selv — da var kun Overrigsadvokaten, ikke Statsadvokaten i Flensborg, kompetent til at begære indledet Undersøgelse og ene og alene Rigsretten i Leipzig, ikke Amtsdommer Lindemann, kompetent til at tage Begæringen til Følge og gennemføre Undersøgelsen (Afhøringen af Hanssen). Og medens Amtsdommer Lindemann med en Begrundelse, hvis Lovstridighed maatte have været ham bekendt, søger at gennemføre sin Opfattelse, holder han - i Modstrid med Landsrettens Kendelse og uanset Statsadvoka-

10) Dagegen sind ausreichende Beweise für die weitere notwendige Feststellung, dass die Einverleibung durch das Mittel der Gewalt ( $81 \mathrm{Nr} .3$ ) bewirkt werden solle und welcher Art diese Gewalt sein würde, nicht beigebracht. Ebenso fehlt es an genügenden Anhaltspunkten für den ferner erforderlichen Nachweis der konkreten Mittel, durch welche das konkrete Endziel erreicht werden soll. Der Hinweis auf das von dem Beschuldigten angegebene Mittel der Ausnutzung des Presse-, Vereins- und Versammlungsrechts zur Verbreitung und Erhaltung dänischen Nationalbewusstseins und der Gewinnung und Erhaltung eines Einflusses auf die Jugenderziehung in diesem Sinne würde nicht ausreichen, solange nicht erkennbar ist, dass jene Ausnutzung und dieser Einfluss eine bestimmt umgrenzte Form, etwa in Gestalt konkreter Organisationen mit obligatorischen Satzungen gefunden hat. Bei jetziger Lage der Sache ist nach der bisherigen Rechtssprechung des Reichsgerichts die Herbeiführung einer Verurteilung aussichtslos . 
tens Anmodning-H. P. Hanssen fængslet.Mon ikke Amtsdommer Lindemann skal takke en naadig Skæbne for, at Sagens originale Akter nu blev "henlagt" hos Statsadvokaten i Flensborg? De rummer saavist "ausreichende Beweise“ imod ham for at have overtraadt en anden Bestemmelse i Straffeloven, den der er rettet imod Frihedsberøvelse. Men hans Interesse for Sagen blev usvækket: Endnu længe efter dens Afslutning har han efter sit Ønske gentagne Gange faaet Akterne udlaant. De ses ogsaa udlaant til Overpræsident v. Steinmann, der tilbagesender dem med en Anordning fra Regeringspræsidenten om skærpet Tilsyn med de danske Forsamlinger.

Medens Amtsdommer Lindemann nu - hvad denne Sag angaar - forsvinder fra Skuepladsen, gør Statsadvokaten i Flensborg i 1896 et nyt Forsøg. Han indberetter nu til Overstatsadvokaten - altsaa i Haab om en Højforræderisag imod Prøjsen $\mathrm{cm}$ en Tale, H. P. Hanssen den 9. Nov. 1896 har holdt i Kolding og fremhæver udtrykkeligt, at der efter hans Mening foreligger Højforræderi. Overstatsadvokaten, der som Gennemgangssted havde videresendt den første Sag til Overrigsadvokaten, sender nu Statsadvokatens Indberetning til den prøjsiske Justitsminister, der ikke anser en Straffeforfølgelse imod H. P. Hanssen for betimelig (,angezeigt") af Hensyn til Bevisvanskelighederne og et Resultats Usandsynlighed, helt bortset fra „Bestemmelsen i den prøjsiske Forfatnings Art. 84, der for Tiden er til Hinder for en saadan Straffeforfølgelse" (H. P. Hanssen var i Marts 1896 bleven valgt som Landdagsmand for Sønderborg-Aabenraa Kreds og nød derfor efter den nævnte Bestemmelse Immunitet, der efter den prøjtiske Landdags Praksis ikke kunde forventes ophævet). 